臨床

\title{
高度の好酸球増多とLöffler's endocarditisを
}

\author{
伴つた好酸球性肺炎の 1 例
}

\section{播種性好酸球性膠原病之Löffler症候群の \\ 疾患概念の検討を含めて}

\author{
東京大学医学部内科物理療法学教室（主任 堀内湖彦教授） \\ 荻野 鉄人 今井康雄 柿内 史堂 \\ 鈴木 修二 野田茂寿 村中 正治 \\ 束京大学医学部病理学教室 \\ 浦野 順文
}

\author{
A CASE OF FATAL EOSINOPHILIC PNEUMONIA WITH \\ LÖFFLER'S ENDOCARDITIS \\ Tetsuhito Ogrno, Yasuo Imar, Terutaka Kakfuchi, Shưjr Suzukr, \\ Motoshi Noda and Masaharu Muranaka \\ Department of Internal Medicine and Physical Therapy, Faculty of Medicine, \\ University of Tokyo (Director: Prof, Yoshihiko Horiuchi) \\ Yoshinori URANo \\ Department of Pathology, Faculty of Medicine, University of Tokyo
}

\begin{abstract}
概要 22 才, 女. 既往歷にアトピ一性皮膚炎（2〜19才）がある. 顏面，手足の腫脹，皮疹，歩行 時の呼吸困難を主訴として来院した，両肺野のびまん性陰影，末梢血で $80 \%$ の成熟型好酸球と $17.5 \%$ の巽型リンバ球を含む 20 万 $/ \mathrm{mm}^{3}$ の白血球增多，著明な好酸球增多を示寸過形成性の骨噵像，肝脾腫， 血清中の L D Hの高值，IgEの増量，お上び好酸球浸潤と異型リンパ球の混在を示寸皮膚生検像を認 めた。主な臨床症状は，肺症状で，しばしば重篤な呼吸困難をきたした。 hydrocortisoneが効果を示 し，定状と胸部X線所見を改善させたが，最後には感染を合併し死亡した．剖検で肺胞内と肺胞壁に 好酸球浸潤を主とする新旧病変がびまん性にあり，aspergillus, pneumocystis cariniiの感染を伴つて いた，左心には内膜下の好酸球浸潤を伴う小塄死巣，壁血栓を認めた。 Löffler’s endocarditis, 播種性 好酸球性翏原病，Löffler's syndrome，好酸球性白血病の疾患概念にかんして若干の考察を加兄た。
\end{abstract}

\section{緒言}

アレルギー疾患は，しばしば好酸球増多を合併

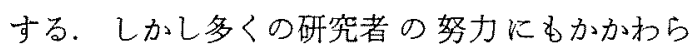
ず，い亦な新好酸球の生物学的作用にかんしては

〔昭和 47 年 2 月 9 日受稿〕
不明の点が少なくない、ステロイドホルモンある いはエピネフリンは末梢血の好酸球を減少させ， また好酸球増多を㧍こす機構にかんしては，好酸 球のヒスタミン走化性や抗原抗体複合物に対する chemotactic activity ${ }^{22}$ ，あるいはいわゆる好酸球 性白血病で代表される，その腫瘍性増殖などが知 
られているが，何れについて子判明しているとこ ろは多くはない。

著者らは最近 20 万 $/ \mathrm{mm}^{8}$ に及ぶ好酸球增多を伴 い，皮膚，肺，心などに多彩な症状を呈し，剖 検所見よりLöffler's endocarditis parietalis fibroplasticaを指摘された症例を経験した。本症は好 酸球の動態あるいは，その生物学的活性にかんし て示唆に富んだ症例と考えここに報告する.

\section{症例}

患者：—，22才，女. 職業は事務 員. 本籍, 東京. 現住所, 東京. 外国在住の経験 なく，特別変つたものを食したこともない，

主挀：顔㧍上び四肢末端の浮腫, 癄㾕感, 歩 行時の呼吸困難.

家族歴：母は気管支喘息の既往があり，卵巣 癌で死亡. 同胞 4 人に血液学的異常を認めない.

既往歴：2才頃より頭頂部，时檗節の屈曲部 に絶えず湿疹がでて，皮虚科通院していたが， 19才頃から消光た（アトピー性皮膚炎上判断され る).

現病歴：昭和45年夏, 頭頂部に噔痒感と脱毛
があり，脂漏性湿疹の診断で，軟高（レダコート ザルべ）を塗布し，秋には治瘉した．この当時の 血算では, 白血球数 $10,700 \sim 8,900 / \mathrm{mm}^{8}$, 好酸球 19〜39\%，異型単核細胞を数\%認めた.

45年秋，家族から顔色がわるい，つやがない， むくんでいるといわれた。

46年1月，スキーによる机んざのためと思われ る左足背部の腫脹に気付いたが，疼痛なく，また 同時に右足背部む腫れた. 左側をぜノールで直接 湿布したところかぶれ，なかなか治らず，入院時 も一部潰瘍化していた。

46 年 2 月, 左腋下の有痛性リンパ節腫脹に気付 いた. $39^{\circ} \mathrm{C}$ 熱が1日でただけですぐ下熱した がリンパ節は次第に大きくなり，約 1 カ月で手 杽大となり，3 月26日切開し，大量の膿がでた。 膿の培養でStaph. aureusを認めた。 cephaloridinの 投与をらけたが切開部の治りが悪く，4月下旬ま で排膿があつた：この当時の検査所見の主なもの を記す之，白血球数 $42,600 / \mathrm{mm}^{3}$ ，好酸球 $89.5 \%$ ， 血沈 $49 \mathrm{~mm} / 1 \mathrm{~h}, \mathrm{~L} \mathrm{DH} 665$ 単位, 胸部X線写真に 異常を認めず，また，両側角径部に小指頭大のリ

Table 1. Laboratory fiindings.

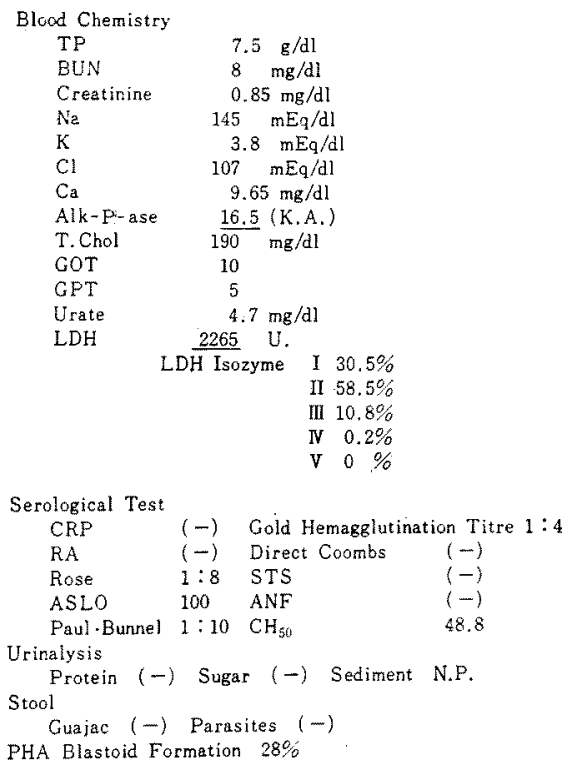

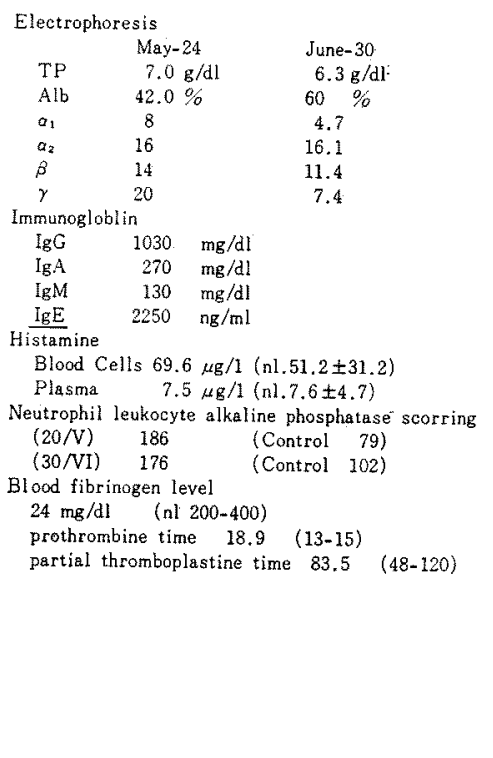


Table 2

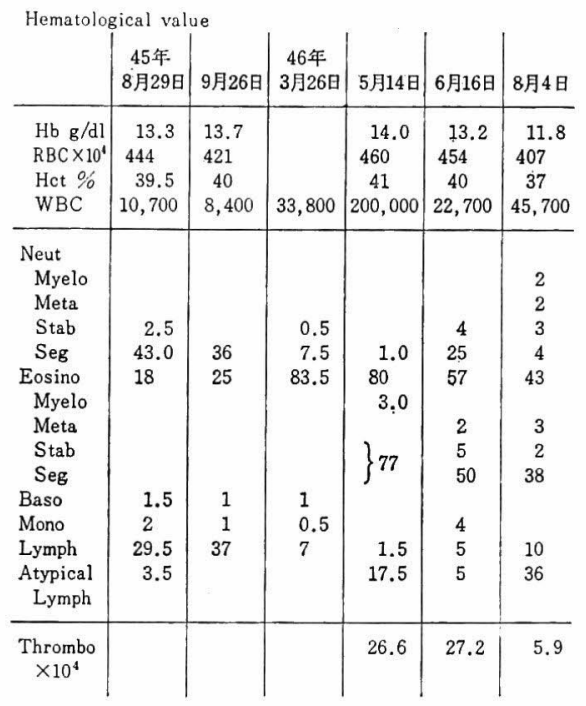

\begin{tabular}{|c|c|c|c|}
\hline \multicolumn{2}{|c|}{$\begin{array}{l}\text { Myelogram } \\
\text { Date }\end{array}$} & 46 年5月15日 & 46 年6月30日 \\
\hline \multirow{2}{*}{\multicolumn{2}{|c|}{$\begin{array}{l}\text { Site } \\
\text { Nucleated cell }\end{array}$}} & sternum & Iliac crest \\
\hline & & $51 \times 10^{4} / \mathrm{cm}$ & $35.55 \times 10^{4}$ \\
\hline \multicolumn{2}{|c|}{ Megakaryocyte } & $160 / \mathrm{c} \mathrm{m} \mathrm{m}$ & 62.5 \\
\hline & 1.6 & 0.4 \\
\hline & & & 0.6 \\
\hline \multicolumn{2}{|c|}{$\begin{array}{c}\text { Neutro.prom } \\
\text { myel }\end{array}$} & & 2.6 \\
\hline \multicolumn{2}{|c|}{ meta } & 0.6 & 7.4 \\
\hline \multicolumn{2}{|c|}{ Stab } & 6.6 & 7.0 \\
\hline \multicolumn{2}{|c|}{ Seg } & 5.8 & 3.6 \\
\hline \multicolumn{2}{|c|}{ Eosino.prom } & 7.8 & 2.4 \\
\hline \multicolumn{2}{|c|}{ myel } & 15.4 & 7.0 \\
\hline \multicolumn{2}{|c|}{ meta } & 13.0 & 6.6 \\
\hline \multicolumn{2}{|c|}{ Stab } & 5.8 & 4.4 \\
\hline \multicolumn{2}{|c|}{ Seg } & 12.0 & 27.6 \\
\hline \multicolumn{2}{|c|}{ Pro.e.bl } & 0.0 & 0.2 \\
\hline \multirow[t]{3}{*}{ Macro } & B & 0.0 & 0.2 \\
\hline & $\mathrm{P}$ & 2.4 & 2.2 \\
\hline & 0 & 0.0 & 0.0 \\
\hline \multirow[t]{3}{*}{ Normob } & B & 0.0 & 0.2 \\
\hline & P & 10.0 & 7.6 \\
\hline & 0 & 0.8 & 0.0 \\
\hline \multirow{2}{*}{\multicolumn{2}{|c|}{$\begin{array}{l}\text { ME ratio } \\
\text { Mono }\end{array}$}} & 5.2 & 6.7 \\
\hline & & & \\
\hline \multicolumn{2}{|l|}{ Lymph } & 17.6 & 9.4 \\
\hline \multicolumn{2}{|c|}{ Plasma cell } & 0.2 & 0.4 \\
\hline \multicolumn{2}{|c|}{ Mast cell } & 0.2 & \\
\hline \multicolumn{2}{|c|}{ Mitosis } & 0.2 & \\
\hline \multicolumn{2}{|c|}{ Naked } & & 4.4 \\
\hline \multicolumn{2}{|c|}{ Destroyed } & & 2.4 \\
\hline \multicolumn{2}{|c|}{ Lymphoid.C } & & 3.4 \\
\hline
\end{tabular}

ンパ節を数コ触れた.

この頃より, 全身に丞痒感のある発疹, 顔面, 両手背, 足背の腫脹が出現し，またほどなく，鼻 汁, 軽度の咳, 軽度の発熱などがあり, 歩行時に 呼吸困難が出現してきた.

5 月 6 日, 当科外来を受診し, $168,000 / \mathrm{mm}^{8}$ に 及ぶ著明な白血球増多, 好酸球 $86 \%$, 胸部 X線写 真でび漫性の陰影を指摘され，5月13日入院し た.

入院時所見：身長 $158 \mathrm{~cm}$ ，体重 $59 \mathrm{~kg}$ ，血圧 $130 / 80$, 体温 $36.8^{\circ} \mathrm{C}$. 顔面, 手足の背部は腫脤し, 痒疹が顔面を除く全身に認められた. 左足背部に ゼノールによるかぶれ，一部潰瘍化を認めた。 下 顎に小指頭大のリンパ節 1 個を触れた. 胸部は打 聴診上異常なく, 心音は純であつた. 腹部で肝を 触れず，やや硬い脾を 2 横指触れた。 反射は正常 で, 自覚的, 他覚的に神経学的異常はなかつた。

\section{臨床検查成績}

䔬便は全経過を通じて奇生虫卵を認めず，尿は

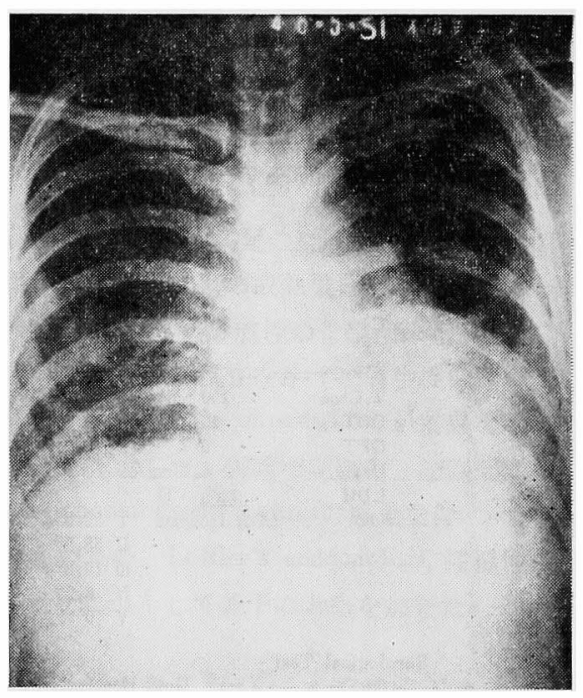

Photo. 1. 胸部X線像(46年 5 月 31 日)両肺野にびま ん性陰影と心陰影の拡大を認める. prednisolone $75 \mathrm{mg}$ 投与中.

入院時正常であつたが，経過中時々蛋白をみた. 血液生化学検査上注目された点をあげると，入院 


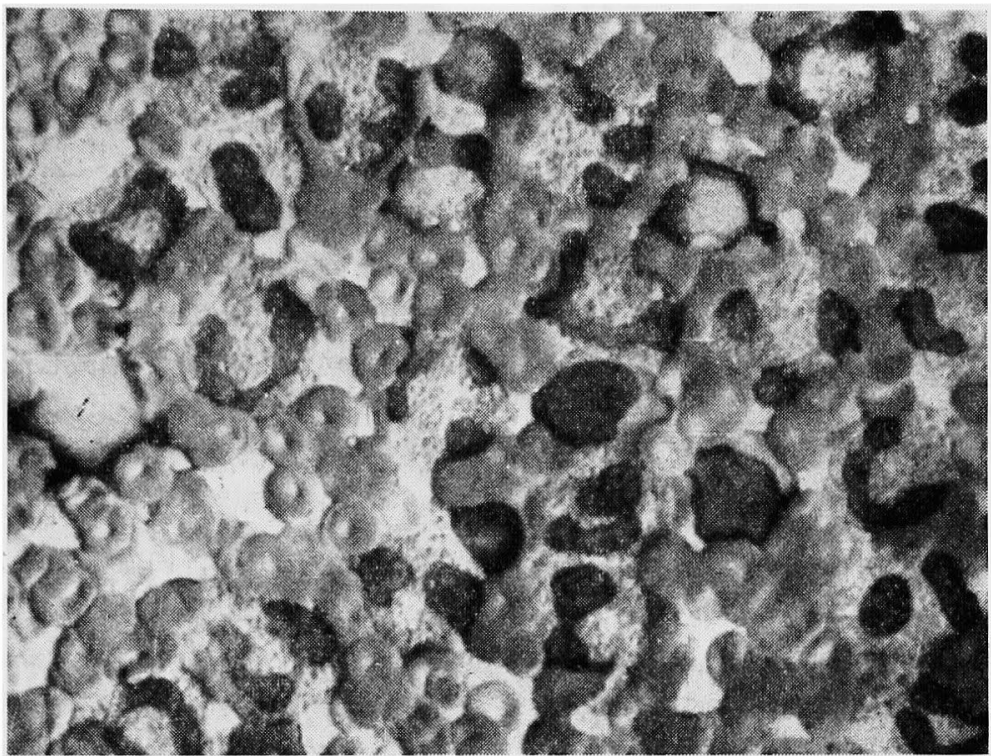

Photo. 2. 末梢血液像. 著明な成熟型好酸球增多を認める.

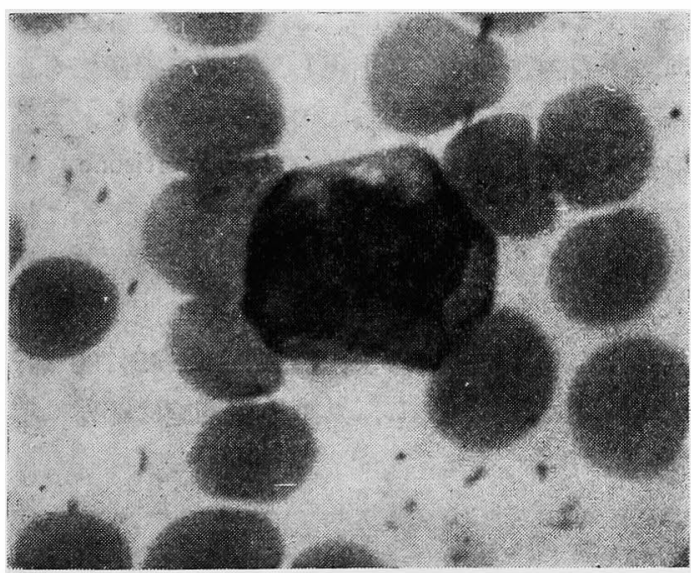

Photo. 3. 末梢血中の異型単核細胞

時alk-P-aseが高值を示したが以後正常化した.

L D H 経過中常に高値で，最高 3,300単位まで 上昇し，肺症状を中心とする臨床経過につれて増 減した. 尿酸值は正常であつた. 蛋白分画で,ガン マグロブリンは20\%で，免疫グロブリンは，IgG， IgA，IgMいずれも正常範囲，IgE は2,250ng/ml と増加している，血清反応で C R P 陰性. 血液 像では, 貧血, 血小板減少はなく, 白血球数は経 過中最高 $239,000 / \mathrm{mm}^{3}$ まで増加し, 好酸球 が 83
\%を占め，その大多数が成熟型で，顆粒の分布お。 よび染色性も正常であつた．多くは 2 核で，過分 葉しているものも認めた．さらに特徽的なのは, 異型単核細胞を認めたことで，比較的大型，大多 数は核にくびれがあり,分葉がさらに強くなり, ク ローバー状のものもあり，核小体を含むものも見 られた。この細胞はperoxidase(一), phagocytosis (一)であつた．末梢血の白血球アルカリフォスフ アターゼ活性は高值を示した.

骨䯣像では，有核細胞数51万と増加し，顆粒球 系が増加して打り，その約 7 割を各成熟過程の好 酸球が占めるほか, 赤芽球系，巨核系には異常な く，末梢血中に認められた異型単核細胞は増加し ていなかつた.

胸部 $\mathrm{X}$ 線像では, 両肺野に散布性の陰影を認 め，経過とともに，心陰影の拡大をみた．末期に は右下肺野に，さらに濃い肺炎様陰影を認めた。

心電図では, sinus tachycardia, 右軸偏位，その 後, III, $\mathrm{a} \mathrm{V}_{\mathrm{F}}, \mathrm{V}_{5}, \mathrm{~V}_{6}$ で $\mathrm{T}$ の逆転を認め, 肢誘導 でlow voltageを認めた.

消化管X線検査で異常を認めなかつた。 


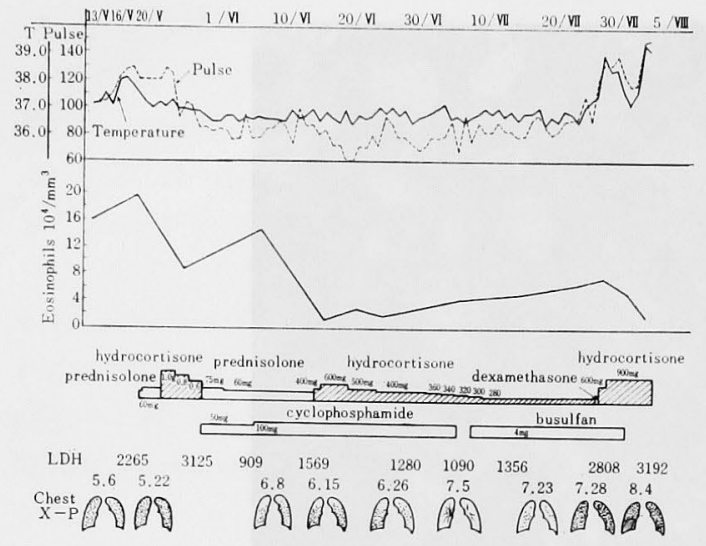

Fig. 1. Clinical course.

呼吸機能は, mild restrictionを思わせる所見 で, DLCo $=16.9 \mathrm{ml} / \mathrm{min} \times \mathrm{mm} H \mathrm{Hg}$ と低下しているが， restrictionのためと思われた.

${ }^{99 \mathrm{~m}} \mathrm{Tc},{ }^{67} \mathrm{Ga}$ よるシンチグラムでは, 軽度の pericardial effusion, hepatomegalyが疑われた。

各種アレルゲンおよび寄生虫抽出液による皮内 テストはすべて陰性であつた。

皮膚生検所見：大腿部皮膚生娭組織は, 皮下 に著明な好酸球のびまん性浸潤があって, 大型の リンパ球様単核細胞が混在しており, 同様の変化 は，程度は軽いが，真皮にも認められた，表皮 は, 棘細胞層の細胞内浮腫があり, 小水胞形成部 は，水胞内に抢びただしい好酸球を認めた。

入院後の経過：入院後約 1 週間 で, 白血球 数 239,000 まで増加し，入院時聴かれなかつた湿 性ラ音が聴取されるようになつた。

prednisoloneを30mgから60mgに増量したが，胸 部異常陰影は著明に増加し, 頻脈, 呼吸困難も 強くなつたので，5月25日より， hydrocortisone 1,000mgを投与したところ, 数日で呼吸困難は消 失し, 胸部陰影も改善し, 白血球数は 11 万に減少 し，皮膚症状も著明に改善した５月28日より， prednisolone $75 \mathrm{mg}$ に変更し，6月1日より60mg, さらにcyclophosphamideを併用したところ，白血 球数は， 6 月 2 日には， 187,200 と増加し，そ の後減少傾向を示し，6月14日には，10万となつ
た. 6 月15日頃より，皮膚に 結節性の 紅斑が出 現し，肺陰影が再び増強した. ふたたびhydrocortisoneにきりかえ，600mgを投与したところ， 2 日後には, 白血球数は， 22,700 (好酸球 $57 \%$ ) と 著明に減少し, 呼吸器症状も改善した. しかし心 陰影は，心肺比で，3 月26日に比べて，10\%程度 の増加が認められた。 以後 7 月10日まで, hydrocortisoneを 300mg まで漸減したが，それにつれ て, 白血球数も増加しはじめ, 好酸球も85\%前後 に、およんでいた。

7 月10日より, cyclophosphamideをbusulfan 变更し， 7 月 19 日, 白血球数 60,200 まで增加した が，患者の一般状態はきわめて良く，歩行も可能 であつた。

しかし，7月20日頃から下肢に浮腫が出現し た. 血清Kの低下が著明なため, 7 月26日，hydrocortisone $280 \mathrm{mg}$, dexamethasone $9 \mathrm{mg}$ にきりか 光たところ， 2 日後には， $38.5^{\circ} \mathrm{C}$ の発熱ととも に, 呼吸困難が急激に出現し, 胸部 X線像です, 入院時と同様の散布性陰影の増強を認めた. 大量 の抗生薬とともに，ふたたびhydrocortisoneを使 用したところ，呼吸困難は，いつたんわずかに軽 減し，下熱もしたが， 8 月 3 日には， $39.5^{\circ} \mathrm{C} に 及$ ぶ発熱とともに，呼吸困難が急激に増悪し，8月 4 日死亡した．このとき白血球数は，45,700（好 酸球 $43 \%$ ）玉で減少し，異型単核細胞は36\%k増 加していた.

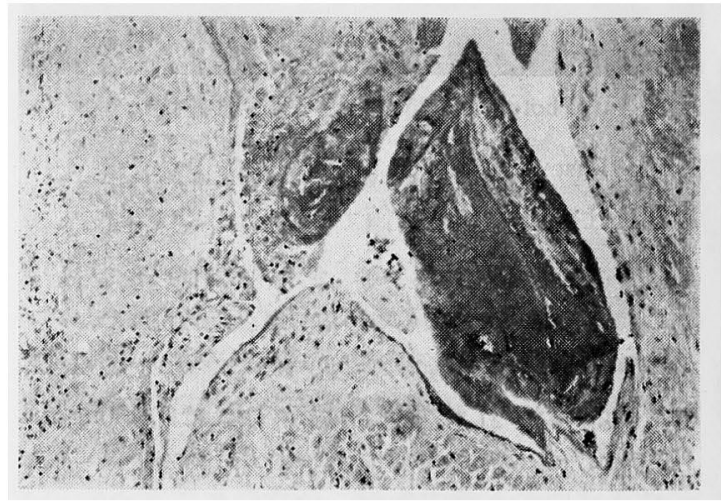

Photo. 4. 左心の壁在性血栓 と心内膜炎と内膜下層 の心筋炎. (HE $4 \times 10)$ 


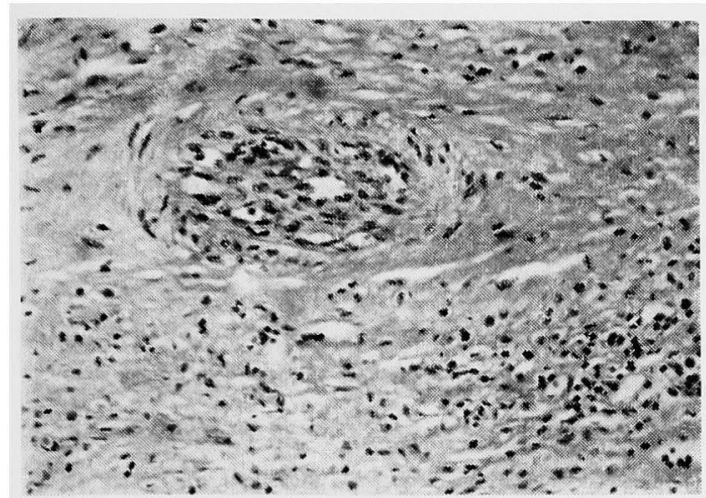

Photo. 5. 心筇炎の病巣には, 好酸球，リンパ球,

形質細胞の浸潤をみとめる。少を動脈の endoarteritis を随伴している。（H E 10×10）

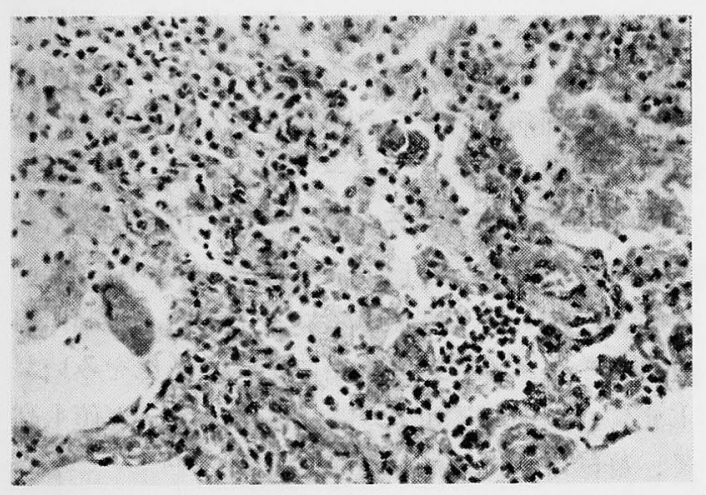

Photo. 6. 肺胞内および肺胞壁には好酸球の著しい 浸㵎と組織球，巨細胞の出現をみる.

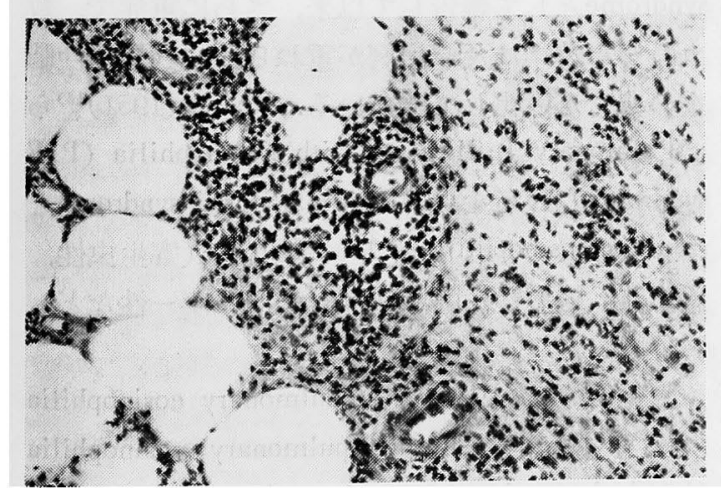

Photo. 7. 皮下に好酸球とリンパ球样細胞の浸潤を みとめる。（H E 10×10）

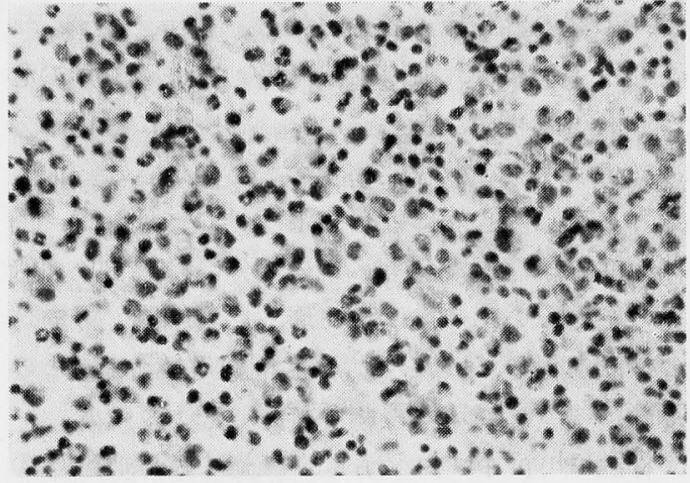

Photo. 8. 骨髄は過形成性を示し好酸球の増加が著 しいが剖検時には生検時より減少している。

(H E $10 \times 10)$

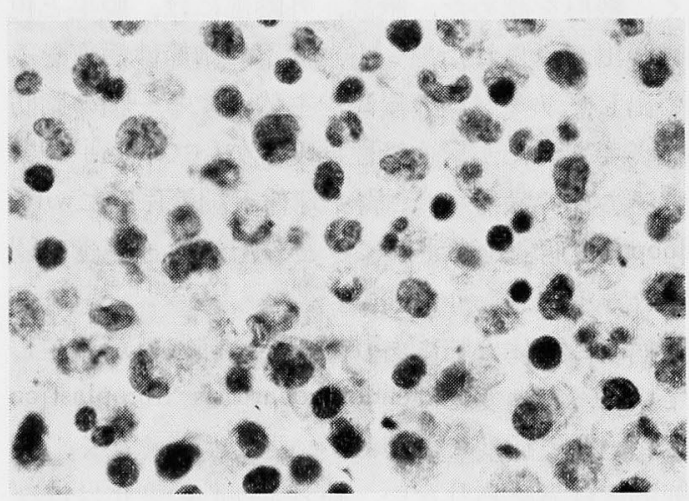

Photo. 9. その強払大, 各種成熟段階の好酸球をみ とめる. (HE $40 \times 10)$

病理所見：肺は, 左 $530 \mathrm{~g}$, 右 $1,100 \mathrm{~g}$ で, 重量が増し, 左 $200 \mathrm{ml}$, 右 $100 \mathrm{ml}$ の胸水を認め た. 左葉には冊指頭大をでの出血巣を認め, 両下 葉には小膿瘍を認めた，組織学的には，肺病変は 多彩で, 肺胞内には，好酸球の浸潤の著しい部 分，組織球，巨細胞の浸潤のある部分，また，線 維芽細胞の增生を伴ら肉芽腫様の部分と，新旧の 病変が混在している. 病変は肺胞内に強いが, 肺 胞中隔にも同様の変化を認める. 出血を伴ら部分 には，血管内にaspergillusの感染性血栓を認め， 肺胞内にも， aspergillusの集塊をみい出す。また 肺胞内には, 蜂巣状の浸出を示寸部分があり, pneumocystis cariniiをみい出す. 後二者の変化 
は，末期の感染症と考えられる。

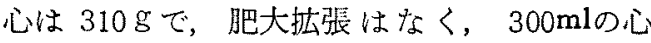
のう液弪認めた，左心室には，心内膜に近い部分 に，小䘫死巣を散在性に認め，また小さな壁血栓 もみとめた，心䇗には，肉眼所見に一致して，肉 芽腫性線維病栄を認め, この部分には，古い血管 资の像をみい㤕し，リンパ球，形質緗胞，好酸球 の浸潤を伴つていた。また心外膜炎を認め，この 部分ではりンパ球の浸潤が著しい。

骨䯣はhyperplasiaを示し，経過中には好酸球の 増加が著しかつたが，剖娭時には，好酸球の増生 は目立ななからた。

剖検時には，皮膚に，進行性の湿疹の病変はな く，曒痕を認めた，腋㝓，外陰部には，脱毛と色 素脱出がみられた。一方，皮下に結節性病变を又 い出し，リンハ球の浸潤を主体とする一種の脂肪 織炎であつたが，血管性病变を欠いていた。

その他の蔵器ては，腎亲球体毛紐管係蹄にwireloop様の病変をわずかにみとめたが，血管炎は認 めなかつた。

病変の主体は肺にあり, 新旧の肺炎巣が存在し ていた，心の変化はendomyocarditis fibroplastica に相当する病変であつたが，程度は強くなく，致 死的とは考学られない，肺括よび心の变化はほ注 同じ古ざ考えられるが，肺病变が，臨床的にも 病理学的にも，本疾患で主役演じ，死园となつ たと解された，抺酸球の浸潤は，末期の血液像に 一致して減少している部分が多い，骨䯣病変は， hyperplasiaを示すが，白血病と考兄られる病像 は，释過中の生娭および剖検でも認められず，反 応性の変化と解された。

\section{考 案}

本症例は末梢血の 20 万 $/ \mathrm{mm}^{8} に$ 及ぶ成熟型好酸 球増多之異型単核細胞の出胃，臨床上の主役を演 じ死因となつた肺病変，特異な皮膚症状，さらに 剖検で認められた心内膜炎之他蔵器への好酸球浸 潤を特色としている。

本症例を診断する上で足がかりとなる主な点 は，1）著明な好酸球増多，2）肺病変，3）心
内膜炎で，それぞれ病変の主体をどこにおくかに 上り，好酸球性白血病，妳酸球性肺炎，Löffler's endocarditisがあけ゚られ，さらにこれらを一つ の系統だつた疾患上考える上，播種性好酸球性 翏原病と, hypereosinophilic syndromeがあげられ る.

1) 好酸球性白血病： Stillman (1912) の症例 以来，好酸球性白血病と乙て報告されたほとえぞ すべての症例で，好酸球が成熟型である点，死因 が心不全である点など，白血病らしから妨さざ まな点から， disease entityとなし得るかどらか， 種々論議888)10143のあるところであるが，末梢血 と骨佮道血に成熟型および幼若型好酸球の著明な增 加があり，骨髄芽球の増殖をきたし，しかも類白 血病反応をたす感染症，奇生虫疾患，悪性腫 癔，古るいは滕原病などを否定でさた場合は，好 酸球性白血病も考克られ得る。ささら最近, 白血 球フルカリフォスファタービ值の測定，フィラデ ルフィア染色体の存在を確認した症例の出現 ${ }^{100}$ どにより，好酸球性白血病もdisease entityとなり つつある. しかし本症例では，末梢血，骨䯣に白 血病にみられる腫瘍性性格にあたる变化をみいだ し充ず，白血球了ルカリフォスファターゼ值も高 く，好酸球性白血病は否定された。

2）好酸球性肺炎：Löffler(1932) ${ }^{21)}$ が核とん ど無症状で, 末梢血中に好酸球增多があり，胸部 $\mathrm{X}$ 線で一過性の肺浸潤が認められた症例をLöffler's syndromeとして報告して以来，さらに重症で，数 カ月から数年に及ぶ症例が重权られ，好酸球性肪 炎の概念が变化してきている. Reeder(1951) ${ }^{15}$ ら はPulmonary Infiltration with Eosinophilia (PIE syndrome）の名を提案し，Löffler's syndrome tropical eosinophilia とPIE syndrome (寄生虫性, 感染性, 腫瘍性, 膠原病性, フレルギー性など) に分類した。

またCrofton(1951) $)^{7} ら は$ pulmonary eosinophilia の名を提案し, simple pulmonary eosinophilia (Löffler's syndrome), prolonged pulmonary eosinophilia, pulmonary eosinophilia with asthma, 
tropical pulmonary eosinophilia, pulmonary eosinophilia with polyarteritis nodosa と分類した. 两 者とも polyarteritis(periarteritis)nodosaの合政が重 症である点で意見が一致している。

さらにCarrington $(1969)^{5)}$ らは，彼等が流血中の 好酸球増多に主点を扣いたのに対し，流血中に好 酸球增多がないのにもかかわらず重症で慢性の経 過をとつた症例で，胸部X線と肺生検により好酸 球の浸潤を確認したものを加えてchronic eosinophilic pneumoniaとして報告している.

多くの症例では，ACTHあるいはhydrocortisone $100 \mathrm{mg}$ 程度が使用され，ほとんど24時間以内に 劇的な効果を示して找り胸部異常陰影も完全に 消失しているのに対し，われわれの症例の上5 に, prednisolone 60mgでも効果を示さず, hydrocortisone 1,000mgを使用した症例は見あたらない し，大量のステロイドにもかかわらず，胸部異常 陰影が完全には消失しなかつた症例もない。血中 の好酸球数と，肺症状特よび胸部陰影とは相関し ないことが知られている以上，われわれの症例 で，たと文好酸球が 20 万 $/ \mathrm{mm}^{3}$ 上他の症例上比較 にならない数であつたとはいえなたか別の要因 が（感染など）加わつているようにも思われる。 3 月26日に白血球数 33,800 で好酸球は $83.5 \%$ を めているのに胸部X線検查で，何ら異常が認めら れないことる興味深い。

われうれの症例で，胸部X線写真で心肺此の増 加をみとめたり，シンチグラムで心のら液の存 在が等われたり，また剖㛟で，心の5液が古り 心外膜炎が存在したが，好酸球性肺炎，Löffler's syndrome, PIE syndromeの应例です，右心不全の 徽候なく，肺性心を否定し得たもので，心陰影の

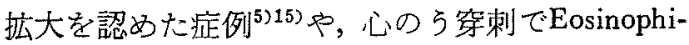
lic pericarditisを確認し得た症例 ${ }^{1113)}$ ，さらに心

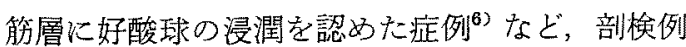
が少ないため数は多くないが，心の桨化を伴らる のるるれてる。

3) Löffler's endocarditis：1936年Löffler ${ }^{22)}$ が, 特翼な心内膜壁在性線維化血栓打よび好酸球增多
を示した 2 症例を, Endocarditis parietalis fibroplastica mit Bluteosinophilieとして報告して以来 Löffler's endocarditis と呼ばれる症例の報告数は 現在までに約50列程度と思われるが，乙の臨㕅症 状は，関節痛，筋闪痛などで始まり，らつ血性心 不全，心肥大，心雑点，肝脾腫大，由血球增多 (好酸球)などで，剖検所見は，心重量增加，心

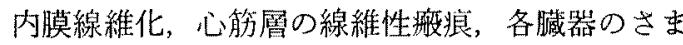
ざまな血管病変（フィブリノイド垶死，血管炎， 動脈内膜の線維性肥厚) などである

好酸球性白血病の症例や，播種性好酸球性㬔原

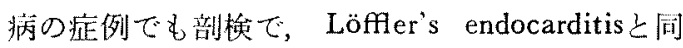
様の变化を認めた症例は非常に䇟く，これらは類 似の疾患と云觉るが，注目すべき異なつた点は， Löffler's endocarditisでは血中の白血球数が減少 しているものがあつたり，好酸球增多のないもの もあることである。初期には好酸球増多は, 組織中 にあり，血中になく，末期には，血中にも組織中に もないここの事実は次のよ5に説明されている。す なわら「組織がeosinophilotactic stimulusk暴露さ れると，好酸球は血中を離れ，その組織に遊走 し，血中の好酸球減少を一定の期間おこさせる.

このあと骨㗓で好酸球増多が括こり，血中扎よび 組織中に好酸球増多が起こる. eosinophilotactic irritantが活動を停止すると血中蛙よび組織中の 好酸球増多がなくなる゙」。このらに考光ると， Davies (1948) が，心闪膜の肥厚，心筋層の洀痕を 有与る36例を，endocardial fibrosisと呼九だ疾患， な Becker (1953) の40例のvascular collagenosis with parietal endocardial thrombosis住, 同一の 疾患の異なつた時期にあるものと理解される。 Roberts (1969) ${ }^{17}$ 恃事故により死亡したLöffler's pneumoniaの患者の心内膜に著明な好酸球浸潤 が見られた報告を参考にして，一端にLöfller's pneumoniaz找き，他端に流血中心好酸球增多が なく，高度の心竻尿の線維症と血栓を有する症例 を和き，この中間に好酸球増多があり，心筋層の 症痕上血栓があまりない例劣考光ている。

4) 播種性好酸球性賿原病： Engfeldt, Zetter- 
$\operatorname{ström}(1956)^{8)}$ は，自験例で，好酸球の浸潤を伴う 間質組織の退行変性と壞死，扣よび血管病変，す なわち，脾の細小動脈をかこむとアリン結合組 織の增加，Zeek(1952)のperiarteritis nodosaの分 類のallergic granulomatous angiitisに酷似する病 変，文献で得たLöffler's syndromeの剖検例にみ られるnecrotizing angiitis associated with eosinophilic granulomata and fibrinoid collagen swelling(Harkavy, 1943 ; Alwall,1943 ; Baley, Lindberg and Baggenstoss, 1945 ; Bergstrand, 1946 ; Pagel, 1951）さらに，高ガンマグロブリン血症，ステロ イドの効果などから, Disseminated Eosinophilic Collagen Desease(DECD) という概念を提唱した。 彼等の症例の一つは，8才の少年で，著明な好 酸球増多 (最高 $79,000 / \mathrm{mm}^{3}$ ), 肝脾腫大, 高ガンマ グロブリン血症 ( $3.5 \mathrm{~g} / \mathrm{dl}, 44 \%)$ があり，Löffler's syndrome と同様の胸部X線像を呈する呼吸困難 をくり返し，6力月で奻若好酸球が出現し，急 性心不全で死亡している. 剖検で, 肺はLöffler's syndromeの像を呈し，忍は，Löffler's endocarditis に相当する変化を来たしている。

Odeberg (1965) ${ }^{14)}$ は，はつきりとLöffler's endocarditisはDECDであるとして，好酸球性白血病と して報告された症例中にDECDでおこされた灯酸 球性類白血病反応の頂点で死んだ症例のある可能 性をあげ，注意深い心臓の顕微鏡的診断でparietal fibroplastic endocarditisすなわちDECDを除外しな ければならないといっている.

われわれの症例飞顿いては，他の翏原病諸疾患 にみられる膠原線維の膨化, 壊死や, 系統的な血管 炎之呼び得る病変がなかつた．賿原病では，第一 義的な病変の主座が翏原組織であるとすると，本 症例がDECDすなわち图原病の亜型であるという 考えには否定的立場に立つものである。もし $1 つ$ の言葉で本症を表わすならば，播種性好酸球性結 合織炎 (disseminated eosinophilic inflammatory connective tissue disease)とでも呼ぶべきであり， DECD といわれるものの評価も再考されるべきて はなかろらか。
5) Hypereosinophilic syndrome: Hardy $(1968)^{12)}$ らはLichtenstein (1964) がeosinophilic granuloma，Schuller-Christian diseaseその他多く 疾患を“histiocytosis X”と総括した如く，“hypereosinophilic syndrome” の症候名で，限局した 良性型として Löffler's syndrome, eosinophilic granulomaから，播種性，熹性型としてDECD.， Letterer-Siwe diseaseまでを包含させている.

われわれの症例は背景にアトピー性皮㲊炎をむ ち，IgEが高値を示しており，hypersensitivityの 状態にあることが示唆される，多くの著者も病因 的に，hypersensitivityをとり西げ，アレルギー， あるいは自己免疫で説明しようとしている．例兄 ばLöffler ${ }^{28}$ は，好酸球増多はアレルギ一反応の表 現であり，アレルギー状態が存続する間は好酸球 増多も存在し，この期間が長いと，心葴に非可逆 的，致命的撚痕を残すと考光ている。

さて本症に乱汀る著明な増加を呈した好酸球の 意義であるが，形態学的に好酸球の顆粒の分布の 異常などがみられた報告1)るあるが，本症例では 全く正常であつた。

患者白血球とSLE患者の血清を使い，LE現象 をみたところ，患者好酸球かLE現象を示してい ることが観察された，患者の好酸球はある程度 正常な機能をもつていると思われる。しかし1 $\mathrm{mm}^{3}$ 中に，20万におよぶ形態学的に成熟した好酸 球を含有しながら，その血球ヒスタミン值は正常 であつた、これは，Graham93の提示した血液ヒスタ ミン值と好酸球值との相関式 $〔 \mu \mathrm{g}$, histamine per liter blood $=1076 \times 10^{-9} \times$ no. basophils per cu. mm. $\times 10^{6}+\left(162 \times 10^{-9} \times\right.$ no. eosinophils per cu. $\left.\left.\mathrm{mm} . \times 10^{6}\right)+43\right]$

にあてはまらない。この式が正しいとすればこ の症例の好酸球は形態的に正常であつても，その ヒスタミン代謝に異常があることになる。このこ とは骨髄性白血病患者の場合，そのヒスタミン值 は，好酸球数上全く相関しないこ上副と考兄合せ て興味樑い。

好酸球の機能にかんして，好酸球の抽出液は七 
ロトニン,ブラディキニン，ヒスタミンの生物学 的効果と拮抗する物質を含んでいることが知られ ている2).

多くの症例で，血栓をみとめたり，生椮後の傷 の治りが悪かつた症例，さらに本症例で血中フィ ブリノーゲンが著明な低值を示したが，Riddle ${ }^{16)}$ が，好酸球の顆粒は線維素溶解素の源泉であるこ とを示し，好酸球は，フィブリンまたはフィブリ ノーゲンによつて炎症の場に牽引され，創傷治癒 機転において重要な役割を果すと推論しているこ とを考えると非常に興味深い.

次にわれわれの症例で見られた異型単核細胞 は, 比較的大型で細胞質は淡い塩基性, 核は不正円 形から,クローバー状をでの種々の形態をとり，と きには核小体を有するものも認められ, peroxidase $(一)$, 墨粒吞食能 (一) で, atypical lymphocyte と思われる.この細胞は，患者の諸症状出現前の 45年夏にも認められ，好酸球の消退との関連は明 確ではなかつた。そして本疾患と病因的あるいは 症候的にどのよらなつながりをもつていたか，現 在のところ全く不明である。文献的には，かかる atypical lymphocyteの出現をみた症例はみあたら なかつたので，今後症例を重权ることによつて樎 討をすすめてゆきたいと考觉る。

\section{結 語}

末梢血の 20 万 $/ \mathrm{mm}^{3}$ に及ぶ成熟型好酸球増多, 異型リンハ球の出現, 特異な肺および皮膚症状を 呈し，剖検により心にLöffler's endocarditis，の初 期像，肺および皮膚などに著しい好酸球浸阔を認 めた症例を報告し, Löffler's endocarditis, disseminated eosinophilic collagen disease, eosinophilic leukemiaなどはdisease entityとして定まらない とこるがあることに言及し，若干の考察を加え た.

（当科入院前の昭和 45 年夏上，46年 3 月の data

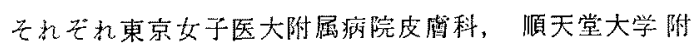

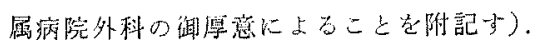

文 献
1) Ackerman A.: Eosinophilic Lcukemia

A Morphologic and Histochemical Study. Blood, 24: 372, 1964. -2) Archer, R.K.: Regulatory Mechanisms in Eosinophil Leukocyte Production, Release, and Distribution-Regulation of Hematopoiesis. Appleton-century crofts edited by Albert S. Gordon, vol. II : 917, 1970. New York. -3) Bousser, J.: Eosinophilie et Leucémie. Sang, 28: 553, 1957. -4) Brink, A. J. and Weber, H.W.: Fibroplastic parietal endocarditis with eosinophilia. Amer. J. Med., 34: 52, $1963 . \quad-5$ ) Carrington, C.B., Addington, W.W., Goff, A.M., Madoff, I. M., Marks, A., Schwaber, J.R. and Gaensler, E. A.: Chronic eosinophilic pneumonia. New Eng. J. Med., 280: 787, 1969. -6) Chafee, F.H., Ross, J.R. and Gunn, E.M.: Eosinophilia in fatal asthma; studies of bone marrow and myocardium. Ann. Intern. Med., 17: 45, 1942. -7) Crofton, J.W., Livingstone, J.L., Oswald, N.C. and Roberts, A.T.M.: Pulmonary cosinophilia. Thorax, 7: 1, 1952. -8) Engfeldt, B. and Zetterström, R.: Disseminated eosinophilic "collagen disease". Acta Med. Scand, 153: 337, 1956. -9) Graham, H.T., Lowry, O.H., Wheelwright, F., Lenz, M.A. and Parish, H.H.: Distribution of histamine among leukocytes and Platelets. Blood. 10: 467, 1955. -10) Gruenwald, H., Kiossoglou, K.A., Mitus, W.J. and Dameshek, W.: Philadelphia chromosome in eosinophilic leukemia. Amer. J. Med., 39: 1003, 1965. -11) Hall, J.W., Kozak, M. and Spink, W.W.: Pulmonary infiltrates, pericarditis and eosinophilia. Amer. J. Med., 36: 135, 1964. - 12) Hardy, W.R. and Anderson, R.E.: The hypereosinophilic syndromes. Ann. Intern. Med., 68: 1220, $1968 .-13$ ) Leckert, J.T.: Loffler's syndrome with cardiac involvement. Arch. Int. Med., 98: 510, 1956. 14) Odeberg, B.: Eosinophilic leukemia and disseminated eosinophilic collagen disease-a disease entity? Acta Med. Scand., 177: 129, 1965. 15) Reeder, W.H. and Goodrich, B.E.: Pulmonary infiltration with cosinophilia (PIE syndrome). Ann. Int. Med., 36: 1217, 1952 . -16) Riddle, J.M. and Barnhart, M.I.: The eosinophil as a source for profibrinolysin in acute inflammation. Blood, 25: 776, 1965 . -17) Roberts, W.C., Liegler, D.G. and Carbone, P.P.: Endomyocardial disease and eosinophilia. Amer. J. Med., 46: 28, 1969. -18) Suzuki, S., Ishida, F., Kono, T. and Muranaka, M.: Histamine contents of blood plasma and cells in patients with myelogenous leukemia. Cancer, 28: 384, 1971 . -19)

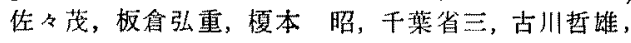
吉野佳一，衣笠恵士，柴田整一：播種性好酸性膠原 病の1例，日内会誌，52:1507, 1964。-20) 福田

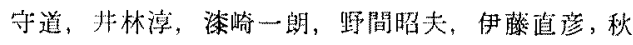
川恵二：周期性波状熱を伴なった播種性好酸球性 翏原病の 1 例，日内会誌，54:229,1965。-21) cited by 7) -22) cited by 4) -23) cited by 17). 